\title{
MANAGEMENT AND INFORMATION IN RURAL AREAS IN DECISION-MAKING PROCESSES BY AGRICULTURAL ENTREPRENEURS
}

\author{
Anna Brzozowska \\ Czestochowa University of Technology, Poland \\ Pavlo Pysarenko \\ Poltava State Agrarian Academy, Ukraine
}

\begin{abstract}
The aim of the paper is to identify technologies designed for diffusion of management and information in rural areas and to define their significance in decisionmaking processes by agricultural entrepreneurs. IT-based specialisation of agricultural holdings is regarded in the paper as the main characteristic of the current stage of modernisation. The current stage of modernisation of rural areas consists in limiting further industrialisation of agricultural holdings by embedding them in networks conducive to sustainable development. Such rooting of agricultural holdings is connected with the development of IT technologies. The paper also shows how important it is to use information in logistics of rural areas, where proper information can speed up the flow of materials, raw materials and services, contributing directly to their rational use. It highlights the use of GIS technology in various aspects of the development of rural areas. Proper combination of information about e.g. agricultural production with spatial data provides material for analysis, which can contribute to optimisation of numerous elements of agricultural activity, such as throughput, production or distribution of agricultural crops.
\end{abstract}

Keywords: knowledge, information, IT technology

DOI: 10.17512/znpcz.2016.1.05

\section{Introduction}

The change of the conditions of functioning of agricultural holdings in rural areas made them more open to external factors whose impact creates production and services environment. A significant part of agricultural entrepreneurs still make decisions following advice from their fathers, neighbours or friends. Meanwhile, a farmer-entrepreneur running a farm is subject to the same market limitations as other economic entities. The necessity to gain competitive advantage on the market forces farmers to increase efficiency and improve effectiveness of farming. Agricultural entrepreneurs should thus more actively use and acquire information (Bernacki 2004, p. 6).

Modern services of provision or exchange of information involve all types of voice, text and image transmissions that carry messages addressed to specific recipients. New techniques, in particular the Internet, allow information to be acquired from a large number of sources distributed all over the world. The issue of the development of the market of modern information services is increasingly applying also to rural areas where it is necessary to improve economic activity and develop entrepreneurship. 


\section{Decision as a consequence of information management}

Decision-making is a complex process that comprises: registration and assessment of information, identification of the decision problem and application of the adopted criterion for choice, definition and issue of the decision and information about its implementation (Griffin 2002]. Decisions connected with management in rural areas, which impact management of a whole farm, are made based on information acquired by farmers from various available sources (Cupiał 2006). The way of managing rural areas depends on the quantity and quality of acquired information.

Traditionally, land, labour and capital are analysed as the main resources of agriculture. This division of production factors was used to describe and analyse both traditional agricultural holdings and changes in their functioning in the period of agriculture industrialisation. Restructuring of capitalism initiated in the last decade of the $20^{\text {th }}$ century (Castells 2011, p. 46), pressure for growth and implementation of this imperative in compliance with the principles of sustainable development (Binswanger 2011) result in management being mentioned among important resources of rural areas (Kulawik, Wieliczko 2012, p. 4, p. 36). It is the quality of management that determines the art of managing other resources - their mobilisation, restructuring or diversification, which ensure transformation of rural areas in multifunctional ones that implement various paths of sustainable development. The increasing importance of management as a production factor is connected with recognition of a hypothesis in economics about the dynamic character of competition and its evolution in changing social structures which create a certain institutional environment and co-management structures.

An intelligent specialisation of IT technologies should lead to change of social structures of regions and has to be connected with all policies, including cohesion policy and common agricultural policy.

Obtaining high quality products in the conditions of sustainable development requires the application of modern methods of management and use of much more information than several decades earlier, which can be facilitated by IT technologies. The quality of decisions made by an agricultural producer is a consequence of many factors and results from character traits, knowledge and skills of the manager. Due to dynamics of processes in an enterprise and its environment, a huge role is played by sources of information. They should ensure information that is complete, accurate, up-to-date and at a reasonable price (Potrzeby informacyjne w przedsiębiorstwem rolnym 2008).

Lack of information makes it difficult to make decisions or leads to making decisions that are wrong in a given situation. Information that is not delivered on time or is delivered in an incomplete form also has an disadvantageous impact on the process of managing a farm (Cupiał 2005, pp. 119-124). Assuming that proper functioning of rural areas to a large extent depends on farmers' activity in acquiring sources of information serving diffusion of information management, the paper proposes that the main characteristic of the present stage of transformation is effectiveness of decision-making in rural areas operating in a turbulent environment. 
The role of information in the modern world is continuously increasing, specifically information about the business environment (Jelonek 2002). Without it there cannot be effective management that allows possessed resources to be rationally used in order to achieve maximum profit and meet the requirements of competition. The necessity of generating products and services of increasing quality to meet the demands of the modern market requires possession of appropriate knowledge and access to up-to-date information ( Pawlak 1998). Lack of information makes it difficult to make decisions or leads to making decisions that are wrong in a given situation.

Transformation of IT technology in the model of rural areas in which (Tomczak 2009, pp. 171-193) - agriculture "shifts from the resource character, with the deciding role of traditional production factors (land, capital, employment), to scientific character, i.e. receptivity for technical, agribiological, organisational and market progress" makes traditional resources change; now they involve human capital and are mobilised, restructured and diversified thanks to knowledge, information and innovations. Processes of rational decisions should be connected with mapping of processes taking place in agricultural holdings. One of the causes of the strategic gap in thinking about the use of IT technologies is the need to manage information in the development of rural areas. It should constitute the theoretical basis for regional strategies for the development of rural areas and agriculture which define the room for IT system in the functioning of rural areas.

\section{Information as an imperative of knowledge}

In modern agricultural management, information is one of the most important resources of every economic entity. Knowledge about market allows you to make decisions that carry less risk regardless of which sector of the economy you are operating in. Information is necessary both to agricultural producers and manufacturers and suppliers of production means as well as recipients of agricultural products. Up-to-date information is necessary in particular for expansive agricultural holdings which modernise their production and introduce modern technologies in crop and livestock production based on proper selection and rational use of technical and energetic means (Kuboń 2007, p. 95).

Due to increasingly emphasised imperative of growth and necessity of its implementation by all sectors of the economy, including rural areas, we can expect that knowledge accumulation will take place much more quickly than before.

In managerial approach to rural areas, we also notice the relationship between the effectiveness of introduced changes and structures of co-management and institutional effectiveness.

Therefore, of importance is knowledge that is necessary for the economic transformation that is currently taking place (Tomczak 2009, pp. 171-193). Effective management of agricultural holdings depends on various types of knowledge.

Like in other sectors of the economy, knowledge is distributed in nature. It is thus necessary to identify sources of various types of knowledge (Bisaga 2009, pp. 143-146). Accessible sources of knowledge and information in a changing environment are the following ones: $\mathrm{TV}$, the Internet, magazines, agricultural 
advisers, training courses, the radio, sales representatives, poviat divisions of the Agency for Restructuring and Modernisation of Agriculture, information from neighbours, gmina's employees, poviat divisions of the Agency for Regional Development, employees of cooperative banks, employees of Agricultural Advisory Centres, Chambers of Agriculture. The most extensive networks are created based on knowledge in the form of: market information, information about necessary adjustment processes to EU's standards, state's agricultural policy and support instruments of the Common Agricultural Policy. The least extensive networks refer to knowledge about possibilities of concluding contracts. The density of networks were assessed by means of concentrations created around specified nodes by type of knowledge and information ( Bubel 2014, pp. 67-69). For instance, strong relationships with agricultural advisers are created in the case of knowledge concerning principles of good agricultural culture and SMR, knowledge concerning Common Agricultural Policy support instruments and knowledge about requirements for farms arising from various EU directives. Due to the inclusion of management of agribusiness into diffusion of knowledge and information, representatives of various corporations build relations with agricultural entrepreneurs thanks to provision of knowledge about quantitative requirements for agricultural raw materials, new species of plants and animals and are a source of market information. Agencies of these corporations participate in the organisation of training courses in new systems of agricultural production. Institutional innovations proposed by network supply chains should be generally positively evaluated. However, they also generate a need for a public institution of managerial representation that would verify provided information.

Spatial information systems in the Polish agriculture

A spatial information system is a process of acquisition, processing and sharing of data containing spatial information and accompanying descriptive information about facilities distinguished in the spatial part covered by the system. Spatial Tools can be also used for supporting rgional e-Entrepreneurship (Jelonek, Pawełoszek, Stępniak, Turek 2015, pp. 988-995). Taking into account accuracy and detailedness of information storage, we distinguish:

- Geographic Information System (GIS) - which is based on processed, secondary information,

- Land Information System (LIS) - which is based on primary information, acquired based on direct field measurements or large scale aerial photographs.

GIS is a system that enables combining various types of data stored in different formats and coming from various sources. It makes it possible to acquire, process, store and analyse data that spatially refers to the surface of earth. This system contains a lot of already mentioned procedures, such as storage, analysis, processing, updating or editing, the use of which depends on possessed software and skills of people that use it.

The numerous functions of the system can be arranged as follows:

- data acquisition,

- data processing,

- presentation of the results. 
GIS makes mechanisms for data gathering and sharing available; the next stage is its proper management - figure 1. It thus enables preliminary verification and selection of data, contributing to its cohesion. The data gathered in the system allows analyses to be conducted on its basis using spatial relations between objects. The results of the analysis may be presented in the descriptive form, in table or - most popular - in the graphical form. It includes maps, graphs or drawings.

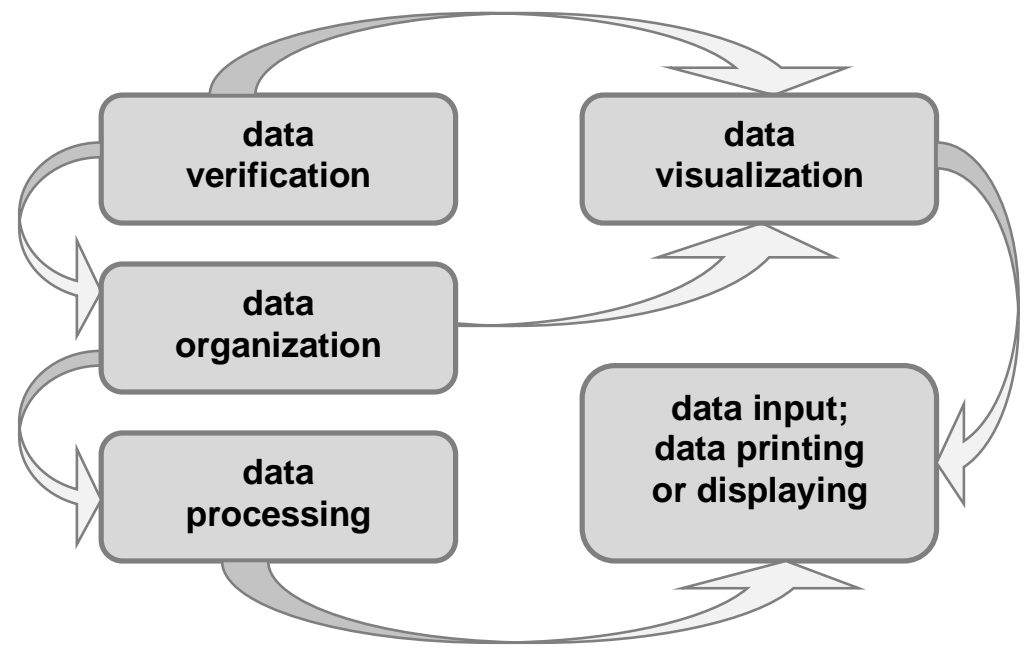

Figure 1. Modular structure of GIS system

Source: Kędzia, Ociepa 2015, p. 201.

The development and increasingly wider application of GIS in recent years created new possibilities not only in the way and scope of data gathering but also in data sharing and processing. Information received thanks to such system is more legible, and can be found more quickly and much more easily. Information legibility impacts drawing proper conclusions based on information, which is significant when conducting large scale spatial analyses and visualisations.

Apart from spatial data, CAD data, information about the form of the landscape, placed in a relatively logical way in a single database, GIS system allows information to be gathered about land survey, GPS measurements, and aerial and satellite pictures. The descriptive data gathered in this system provides information about the use of fields, individual agricultural or forest areas, or areas used for agricultural purposes. GIS enables description of the surrounding reality in a comprehensive way that has never been more accurate.

The constituents of GIS include: gathered data, algorithms and procedures for data processing and sharing, computer equipment and software, as well as people creating and using the system. As a source of data, GIS uses information from the real world, which is different in character and has different origins. Nowadays, possibilities of data acquisition are practically unlimited - it is possible to take pictures by means of satellite navigation or aerial pictures. 
The use of GIS is based on metadata (i.e. data about data) which makes it easier to manage possessed resources and find a detailed description of a given object in a clear and simple way. For the purpose of writing it, various, sometimes generally available text files, XML files, table records or databases are used.

Management of metadata will significantly improve its saving in a clear form, regardless of what system was used to save it and what skills the man who created it possessed. An important advantage of metadata is that compared to the size of spatial data its size is small, which makes it easier for it to be transmitted. Therefore, information about the existing data is easily available to all users in a given institution. The plus of metadata is also the fact that it is no longer necessary to make copies or duplicates, as it is appropriately catalogued and described.

Data available in GIS can be divided into two groups:

- spatial data (spatial attributes) - which defines the location and shape as well as topographical relationships with other objects, showing thus the location of an object and its character,

- descriptive attributes - textual and descriptive data, which provides characteristic quantitative and qualitative data with respect to an object.

Recent years have seen a dynamic development of spatial information systems worldwide. GIS is used in a number of economic sectors, such as geology, forest management or environmental protection. In agriculture, the use of GIS provides unusual possibilities, both at the micro and macro levels, and can be a tool for optimising the whole production cycle, ending in appropriate distribution.

An example of the level of spatial information infrastructure in Poland may be Land Parcel Identification System (LPIS), which is maintained by the Agency for Development and Modernisation of Agriculture. The GIS technology enables integration of data from registers of land and buildings; it contains cadastral maps, vector boundaries of plots which are e.g. eligible for payments, and much more other data that complements information available in the system.

At the regional level, geographical information systems are mainly used in precision farming where various works and their scope can be planned using data on the form of the landscape, chemical composition of the soil, productivity, meteorological forecast. By means of GIS, the Chief Sanitary Inspectorate in Poland monitors the quality of potable water at the regional level. Selected points of monitoring have been established and then spatially visualised and complemented with data on the topography from a vector map. Additionally, in the case of testing the quality of water it is also possible to gather information about the chemical composition of water to assess and describe the levels of concentration of chemical compounds. The data gathered on this basis may be used to conduct analyses at the regional or national levels.

Current features of GIS systems, maintaining standardisation in the area of making spatial information available, can be used for the purpose of the global infrastructure of global network.

GIS technology allows to create comprehensive solutions based on development of systems whose functionality can be designed specifically for the needs of the agricultural market. GIS systems provide server technologies, desktop software and enable work directly in the field via using mobile devices. 
Geographical information systems, due to their capabilities, should become a common platform for many systems and activities in the area of management of rural areas, their proper use, development and modernisation. Their use, both regionally and on the scale of the whole country, may significantly contribute to efficient transmission and processing of information coming from distributed and varied sources.

GIS systems are essentially used to build, catalogue and store data at the level of a country or region; they are designed to be used by specialised agencies or government agencies to create a coherent and relatively comprehensive information system. Such information may facilitate a better use of the potential of rural areas, and help in attempts to obtain funds or use uncultivated land.

\section{Precision farming as an example of the development and applications of ICT}

Recent years have seen intensification of changes to the natural environment. This impacts the quality of production and the quantity of received crops. In order to minimise losses due to unfavourable conditions, more and more attention is given in recent years to precision farming.

Precision farming, due to increasing changeability of the soil structures, also with reference to agro-technics, observed even in fields belonging to one enterprise or farm, is becoming an increasingly important element of agriculture. Changes in the characteristics of the soil, heterogeneity of the mineral composition and other physical and chemical properties often make it necessary to use variable, sometimes different, dozes of production means. As this trend is set to continue and even deepen, precision farming should be regarded as one of important prospective production systems.

According to the most general definition, precision farming consists in the use of differentiated doze of production within a field that matches the real needs. As a result of the development of various systems of precision farming, a farm may use differentiated dozes of fertilisers, plant protection products as well as seed and other necessary means. Some theoreticians regard precision farming as a management strategy which, based on the evaluation of the characteristics of plants, their development, as well as weather conditions, enables the use of variable dozes of fertilisers or plant protection products, seed or working parameters of machines to optimally use the soil resources and production potential of plants. It is also important that these activities are possibly least harmful for the environment. With such an approach to precision farming it is obvious that its functioning is based on the use of highly advanced navigation and information technologies, namely:

- GPS satellite location systems,

- GIS spatial methods and systems.

The foundation in precision farming is the GPS technology; the quality of work performed by machines interacting with this technology relies on accuracy of signals from a Differential Global Positioning System (DGPS). Signal 
Interference may have various sources, but they can be verified, as additional signals can correct errors of the signals transmitted earlier. This operation can be carried out using two GPS receivers; one is positioned in a specific place in the ground, while the other inside a working machine. For the system to be able to function relatively properly, it is necessary to have own reference station within fields where agro-technical operations are performed. Placing such a station provides high probability that the accuracy of performed activity will be at the level of several centimetres.

Using GPS, it is possible to take measurements of the surface, examine mineral substances of the soil, gather data about crops to create the so-called maps of crops. Later, it can be used to determine fertilisation in the real time. However, errors may occur when performing works using this system. i.e.:

- certain works can be performed twice in a given field,

- a certain area of a field can be omitted, with no works performed on it.

Flaws of this type can be avoided by using the so-called parallel driving system - an appliance installed in a machine works with GPS signal and the computer should show the correct track, parallel to the previous track of the machine.

Precise definition of the parameters of fertiliser or seed dozes allows for optimal use of these agents and leads to savings in the long-run - it will be easier to define real material needs in the future. The quantity of the agents transported directly to the field may decrease. We can expect the following as the result of activities as part of precision farming:

- improvement of the individual processes,

- better and rational use of agricultural machines and devices,

- appropriate application of plant protection products, which can decrease their use and reduce costs,

- possibility of more precise definition, based on earlier developed map of crops, of demand for their transport,

- systematisation and detailing of information on production processes.

Undoubtedly, precision farming is an excellent chance for appropriate use of the potential of a given agricultural holding, optimisation of costs and expenses. However, at the present level of development very high costs of the purchase of specialist GPS devices, on-board computers or reference stations constitute a significant barrier that limits its use. The investment repayment period is relatively long and the present development of a precision farming involves joint investments by a group of enterprises or a group of farmers, especially that the system can be optimally used in the areas of large, distributed farms.

\section{Summary}

The material presented in the paper can also be interpreted in a broader way. It confirms that rural areas are entering another stage of transformation where their development is determined not only by traditional production factors (land, capital, labour), but also by management, information, IT information and knowledge, which facilitate economic progress of rural areas. 
Changes connected with this stage of transformation refer to:

- types of knowledge identified as necessary for management of rural areas,

- restructuring of agricultural holdings in the process of modernisation in real and virtual spaces,

- participation of sales representatives in the process of knowledge and information diffusion

- institutional innovations.

The modernisation processes that are taking place do not exclude the use of traditional sources of knowledge and information in rural areas, such as the television or magazines. The role of the Internet as a tool for learning is dynamically increasing.

At the present stage of IT transformation in rural areas, information is becoming a fundamental factor that gives production and services resources in agriculture the economical value that determines their usability. In these circumstances, the main challenge facing IT is to strengthen the innovation capacity of rural areas and speed up technological, organisational and social progress. From this perspective, IT information has to be embedded in the system of agricultural management and information and implement the objectives of regional strategies of rural area development.

\section{References}

1. Bernacki A., Informatyka $w$ gospodarstwie rolniczym. Materiały konferencyjne, „Nowoczesne techniki informacyjne w nauce, edukacji i doradztwie dla wsi i rolnictwa”, Materiały konferencyjne, Brwinów. Warszawa 2004, p. 6.

2. Binswanger H.Ch., Spirala wzrostu. Zysk i S-ka Wydawnictwo, Poznań 2011.

3. Bisaga A., Mapowanie wiedzy jako instrument zarządzania $w$ rolnictwie. Współczesne Zarz.ądzanie 4/2009, pp. 143-146.

4. Bubel D., Management of Knowledge and Information in Logistic Processes. Logistyka 2014, no. 3, pp. 67-69.

5. Castells M., Społeczeństwo sieci. Wyd. Nauk. PWN, Warszawa 2011, p. 46

6. Cupiał M., Informacja techniczna w rolnictwie Matopolski. Inżynieria Rolnicza. Nr 3(63), Kraków 2005, pp. 119-124.

7. Cupiał M., System wspomagania decyzji dla gospodarstw rolniczych. Inżynieria Rolnicza $\mathrm{Nr} 9$ (84). Kraków 2006. ISSN 1429-7264.

8. Griffin R.W., Podstawy zarządzania organizacjami. PWN. Warszawa 2007.

9. Jelonek D., Pawełoszek I., Stępniak C., Turek T., Spatial Tools for Supporting Regional e-Entrepreneurship. ICCMIT 2015. International Conference on Communications, management, and Information technology (ICCMIT'2015), Procedia Computer Science, 2015, Vol. 65, pp. 988-995.

10. Jelonek D., Systemy komputerowego wspomagania monitorowania otoczenia przedsiębiorstwa. Wydawnictwo Wydziału Zarządzania Politechniki Częstochowskiej, Częstochowa 2002.

11. Kędzia W., Ociepa E., Systemy informacji przestrzennej GIS w zarzadzaniu infrastruktura wodociagowa i kanalizacja. Inżynieria i Ochrona Środowiska 2015, vol. 18, no. 2, p. 201.

12. Kuboń M., Poziom wyposażenia $i$ wykorzystania elementów infrastruktury informatycznej w gospodarstwach o różnym typie produkcji rolniczej. Inżynieria Rolnicza 9(97). Kraków 2007, p. 95. 
13. Kulawik J., Wieliczko B., Wybrane finansowe aspekty konkurencyjności rolnictwa. Zag. Ekon. Rol. 2012, p. 4, p. 36.

14. Pawlak J., Znaczenie informacji dla rolnictwa. IBMER, Warszawa 1998.

15. Potrzeby informacyjne $w$ przedsiębiorstwem rolnym [online]. [access date 02-02-2008] Available on the Internet: http: //www.dss.iung.pulawy.pl/Documents/ipr/eneeds.html.

16. Tomczak F., Wyzwania $i$ sity rozwojowe wsi $i$ rolnictwa $w$ warunkach globalizacji gospodarki światowej [in:] Wokót trudnych problemów globalnego rozwoju obszarów wiejskich, gospodarki żywnościowej i rolnictwa. eds. K. Kuczkowska-Małysz, A. Szymecka, Oficyna Wydawnicza SGH, Warszawa 2009, pp. 171-193.

\section{ZARZĄDZANIE I INFORMACJA NA OBSZARACH WIEJSKICH W PROCESACH PODEJMOWANIA DECYZJI PRZEZ PRZEDSIĘBIORCÓW ROLNYCH}

Streszczenie: Celem opracowania jest identyfikacja technologii służących dyfuzji zarzadzania i informacji na obszarach wiejskich oraz określenie ich znaczenia w procesach podejmowania decyzji przez przedsiębiorców rolnych. Opartą na technologii informacji IT specjalizację gospodarstw rolnych uznano w opracowaniu za główną cechę obecnego etapu modernizacji. Obecny etap modernizacji obszarów wiejskich polega na ograniczeniu dalszej industrializacji gospodarstw rolnych przez ich osadzenie w sieciach społecznych sprzyjających zrównoważonemu rozwojowi. Takie ich zakorzenienie jest związane z rozwojem technologii IT. W artykule wskazano również, jak ważne jest wykorzystanie informacji w logistyce obszarów wiejskich, gdzie odpowiednia informacja jest w stanie przyspieszyć przepływ materiałów, surowców i usług, przyczyniając się pośrednio do racjonalnego ich wykorzystania. Zwrócono uwagę na zastosowanie technologii GIS w różnych aspektach rozwoju obszarów wiejskich. Właściwe połączenie informacji na temat np. produkcji rolnej z danymi przestrzennymi dostarcza materiału do analizy, która może przyczynić się do optymalizacji wielu elementów działalności rolniczej, jak przerób, produkcja czy dystrybucja płodów rolnych.

Słowa kluczowe: wiedza, informacja, technologie IT 